\title{
Living Polymerizations of Alkyl Acrylates by the Unique Catalytic Action of Rare Earth Metal Complexes
}

\author{
By Eiji Ihara, Masakazu Morimoto, and Hajime Yasuda*) \\ Department of Applied Chemistry, Faculty of Engineering, Hiroshima University, \\ Higashi-Hiroshima 739 \\ (Communicated by Seizo OKamura, M. J. A., April 12, 1995)
}

\begin{abstract}
Rare earth metal complexes such as $\mathrm{SmMe}\left(\mathrm{C}_{5} \mathrm{Me}_{5}\right)_{2}(\mathrm{THF})$ or $\mathrm{YMe}\left(\mathrm{C}_{5} \mathrm{Me}_{5}\right)_{2}(\mathrm{THF})$ catalyze the living polymerization of alkyl acrylates (alkyl $=\mathrm{Me}, \mathrm{Et}, \mathrm{nBu}, \mathrm{tBu}$ ) to give high molecular weight polymers with extremely low polydispersity in high conversion. Random living copolymerization of methyl acrylate with butyl acrylate was also successful by the catalytic action of $\mathrm{SmMe}\left(\mathrm{C}_{5} \mathrm{Me}_{5}\right)_{2}$ (THF). By taking advantage of the living polymerization ability of alkyl acrylates and alkyl methacrylates, a triblock copolymerization of methyl methacrylate/butyl acrylate/methyl methacrylate was performed to find rubber-like elastic properties. As a result, 8:72:20 block-copolymer was found to exhibit the desired elastic character, which showed the elongation properties of $163 \%$ and compression set of $58 \%$.
\end{abstract}

Key words : Living polymerization; living copolymerization; alkyl acrylate; rare earth metal complexes; $\mathrm{LnMe}\left(\mathrm{C}_{5} \mathrm{Me}_{5}\right)_{2}(\mathrm{THF})(\mathrm{Ln}=\mathrm{Sm}, \mathrm{Y})$; monomer reactivity ratio.

Introduction. A vast majority of polymerization of alkyl acrylates has long been explored with radical initiators which afford the polymers of rather broad molecular weight distribution. In general, living polymerizations of alkyl acrylates have been hampered due to the predominant nucleophilic attack of the acidic $\alpha$-CH. ${ }^{1)}$ More recently, bulky alkyllithium/inorganic salt ( $\mathrm{LiCl}$ or $\mathrm{NaCl}$ ) initiator systems were found to produce the living polymer of a bulky alkyl acrylate, t-butyl acrylate $\left(M_{\mathrm{n}}=23,000, \quad M_{\mathrm{w}} / M_{\mathrm{n}}=1.05\right)^{2), 3)}$ Furthermore, Group Transfer Polymerization of ethyl acrylate provides living polymers when $\mathrm{ZnI}_{2}$ was used as catalyst $\left.\left(M_{\mathrm{n}}=3300, M_{\mathrm{w}} / M_{\mathrm{n}}=1.03\right){ }^{4}\right)$ Aluminum-porphyrin initiator systems also afford the living polymer of t-butyl acrylate $\left(M_{\mathrm{n}}=12,200, \quad M_{\mathrm{w}} / M_{\mathrm{n}}=1.13\right) .{ }^{5)}$ However, upper limit of molecular weights of resulting polymers is approximately 20,000 . We describe herein more efficient initiating property of $\mathrm{SmMe}$ $\left(\mathrm{C}_{5} \mathrm{Me}_{5}\right)_{2}(\mathrm{THF})^{6)}$ and $\mathrm{YMe}\left(\mathrm{C}_{5} \mathrm{Me}_{5}\right)_{2}(\mathrm{THF})^{7)}$ as initiator for living polymerization of alkyl acrylates. By taking advantage of living polymerization ability of both alkyl acrylates and alkyl methacrylates, a triblock copolymerization of methyl methacrylate (MMA)-butyl acry-

*) Correspondence to: H. Yasuda. late $(\mathrm{nBuA})-\mathrm{MMA}$ was performed with organolanthanide(III) complexes to find rubber-like elastic property.

Experimental. Living polymerization of methyl acrylate by $\mathrm{SmMe}\left(\mathrm{C}_{5} \mathrm{Me} e_{5}\right)_{2}(\mathrm{THF})$. A catalyst, $\mathrm{SmMe}\left(\mathrm{C}_{5} \mathrm{Me}_{5}\right)_{2}$ (THF) $(0.01 \mathrm{~g}, 0.02 \mathrm{mmol})$, was dissolved in $1.0 \mathrm{~mL}$ of toluene. Catalyst concentration was adjusted by dissolving appropriate amount of the solution in $20 \mathrm{ml}$ of toluene. To the diluted solution was added $0.9 \mathrm{ml}$ of $\mathrm{MeA}(10 \mathrm{mmol})$ with a syringe at $0^{\circ} \mathrm{C}$ with vigorous magnetic stirring. The stirring was continued for $10 \mathrm{~min}$ at $0^{\circ} \mathrm{C}$. Then the mixture was poured into excess $\mathrm{MeOH}$ and resulting polymer was dried in vacuo. Typical yield, $99 \%$.

Triblock copolymerization of MMA-BuA-MMA. Methyl methacrylate $(0.2 \mathrm{~mL}, 2 \mathrm{mmol}, \mathrm{MMA})$ was added to the toluene solution $(20 \mathrm{~mL})$ of SmMe$\left(\mathrm{C}_{5} \mathrm{Me}_{5}\right)_{2}(\mathrm{THF})(0.01 \mathrm{~g}, 0.02 \mathrm{mmol})$ at $0^{\circ} \mathrm{C}$ with vigorous magnetic stirring. The stirring was continued for $30 \mathrm{~min}$ and then butyl acrylate $(1.12 \mathrm{~mL}, 8 \mathrm{mmol}$, $\mathrm{nBuA}$ ) was added at $0^{\circ} \mathrm{C}$. After stirring the mixture for $10 \mathrm{~min}$, freshly distilled MMA $(0.2 \mathrm{~mL}, 2 \mathrm{mmol})$ was further added at $0^{\circ} \mathrm{C}$ and stirring was continued for $30 \mathrm{~min}$. Then the mixture was poured into $\mathrm{MeOH}$ $(50 \mathrm{ml})$. 
Table I. Polymerization of alkyl acrylates catalyzed by organolanthanide complexes at $0^{\circ} \mathrm{C}^{\mathrm{a}}$

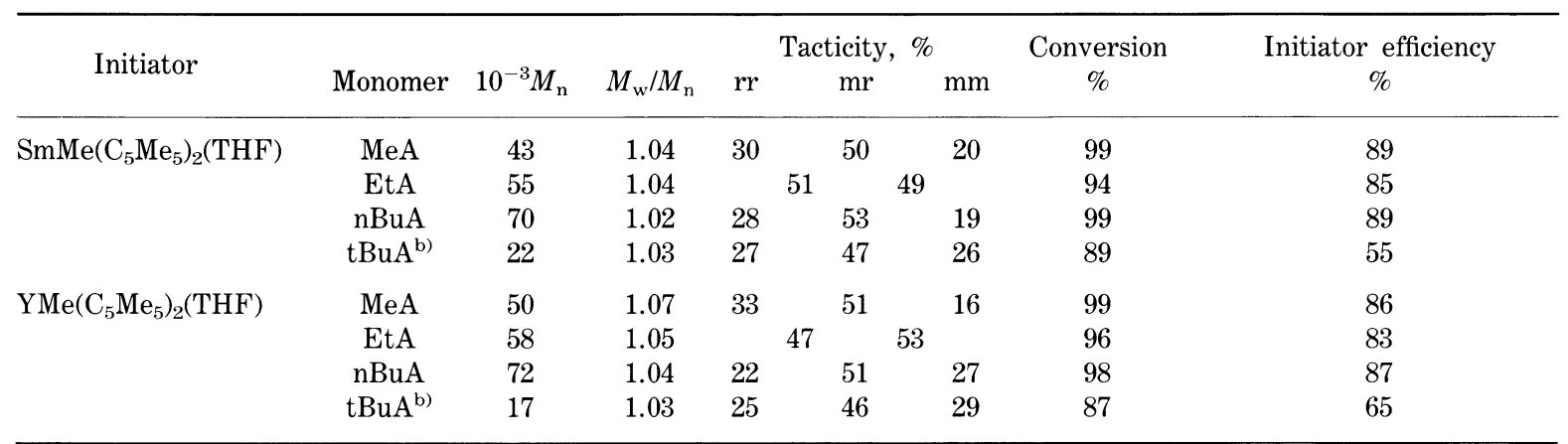

a) Reaction conditions: initiator concentration, $0.2 \mathrm{~mol} \%$ of monomer; solvent, toluene; reaction time, $10 \mathrm{~min}$.

b) Reaction conditions: initiator concentration, $1.0 \mathrm{~mol} \%$ of monomer; solvent, toluene; reaction time, $24 \mathrm{~h}$.

Results and discussion. Living polymerizations of alkyl acrylates. Methyl acrylate (MeA), ethyl acrylate (EtA), butyl acrylate $(\mathrm{nBuA})$ and t-butyl acrylate (tBuA) were polymerized with $\mathrm{SmMe}\left(\mathrm{C}_{5} \mathrm{Me}_{5}\right)_{2}(\mathrm{THF})$ or $\mathrm{YMe}\left(\mathrm{C}_{5} \mathrm{Me}_{5}\right)_{2}$ (THF) in toluene at $0^{\circ} \mathrm{C}$ and the results of polymerizations were summarized in Table I. The initiator efficiency exceeds $80 \%$ in every cases except for tBuA system. Therefore, we can conclude that these polymerizations proceed in a living fashion. In fact, $M_{\mathrm{n}}$ of poly (butyl acrylate) initiated by $\mathrm{SmMe}\left(\mathrm{C}_{5} \mathrm{Me}_{5}\right)_{2}(\mathrm{THF})$ increases linearly in proportion to the conversion, while $M_{\mathrm{w}} / M_{\mathrm{n}}$

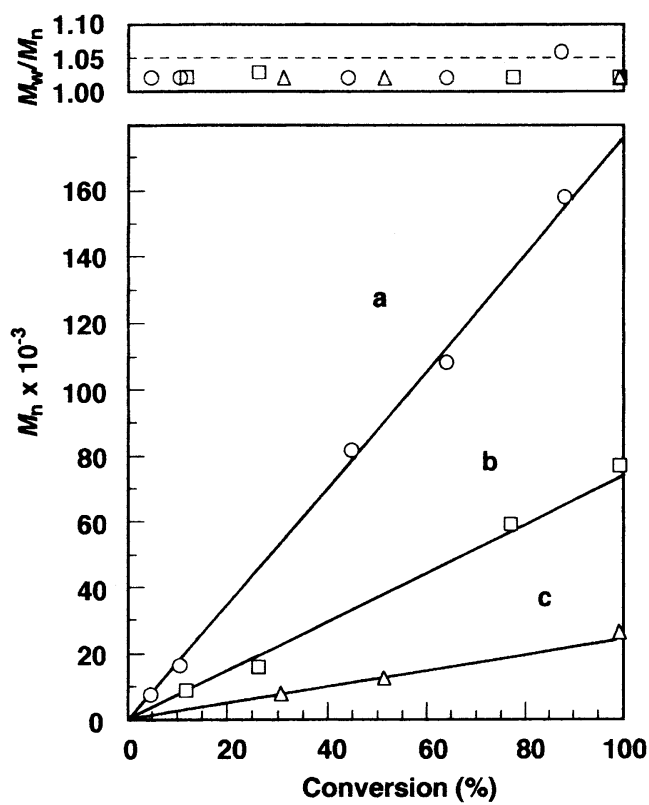

Fig. 1. $M_{\mathrm{n}}$ and $M_{\mathrm{w}} / M_{\mathrm{n}}$ vs. conversion plots for polymerization of n-butyl acrylate $\mathrm{SmMe}$ $\left(\mathrm{C}_{5} \mathrm{Me}_{5}\right)_{2}(\mathrm{THF})$, a) $0.1 \mathrm{~mol} \%$, b) $0.2 \mathrm{~mol} \%$ and c) $0.5 \mathrm{~mol} \%$. remains intact holding narrow molecular weight distributions irrespective of the initiator concentration (Fig. 1). The $M_{\mathrm{n}}$ of poly (MeA) and poly (EtA) again increased in proportion to the conversion when the initiator concentration was fixed to $0.2 \mathrm{~mol} \%$ of monomers.

The apparent rate of polymerization is very fast and it follows the order, $\mathrm{nBuA}>\mathrm{EtA}>\mathrm{MeA}$, while the order was reversed in the case of methacrylic ester system, MMA $>$ EtMA $>$ nBuMA. The observed apparent rate of polymerization of $\mathrm{MeA}$ initiated by $\mathrm{SmMe}\left(\mathrm{C}_{5} \mathrm{Me}_{5}\right)_{2}(\mathrm{THF})$ is $3.59\left(\mathrm{sec}^{-1}\right)$ and those of EtA and $\mathrm{nBuA}$ are $130\left(\mathrm{sec}^{-1}\right)$ and $134\left(\mathrm{sec}^{-1}\right)$, respectively, at $0^{\circ} \mathrm{C}$. By lowering the polymerization temperature to $-78^{\circ} \mathrm{C}$, the apparent rate of polymerization decreased significantly, i.e. MeA $0.0001\left(\mathrm{sec}^{-1}\right)$, EtA 0.0543 $\left(\mathrm{sec}^{-1}\right), \quad \mathrm{nBuA} 0.0805 \quad\left(\mathrm{sec}^{-1}\right) . \quad \mathrm{YMe}\left(\mathrm{C}_{5} \mathrm{Me}_{5}\right)_{2}(\mathrm{THF})$ initiated polymerizations of $\mathrm{MeA}, \mathrm{EtA}$ and $\mathrm{nBuA}$ show the similar rate of polymerization as those of $\mathrm{SmMe}\left(\mathrm{C}_{5} \mathrm{Me}_{5}\right)_{2}(\mathrm{THF})$, i.e. at $0^{\circ} \mathrm{C}, 3.06,33.6$ and 66.6 $\left(\mathrm{sec}^{-1}\right)$ was observed for MeA, EtA and $\mathrm{nBuA}$, respectively, and at $-78^{\circ} \mathrm{C} 0.0487$ and $0.0501\left(\mathrm{sec}^{-1}\right)$ was observed for EtA and $\mathrm{nBuA}$. When the polymerization temperatures were raised to $60^{\circ} \mathrm{C}$, $M_{\mathrm{w}} / M_{\mathrm{n}}$ values became broader (polymerization time, $10 \mathrm{~min}$ ) and conversion became smaller, i.e. poly (MeA) $M_{\mathrm{w}} / M_{\mathrm{n}}=1.33, M_{\mathrm{n}}=47 \times 10^{3}$, conversion $50 \%$; poly(EtA) $M_{\mathrm{w}} / M_{\mathrm{n}}=1.26, M_{\mathrm{n}}=65 \times 10^{3}$, conversion $69 \%$; poly $(\mathrm{nBuA}) M_{\mathrm{w}} / M_{\mathrm{n}}=1.26, M_{\mathrm{n}}=99 \times 10^{3}$, conversion $73 \%$. Thus the polymerizations of alkyl acrylates gave the polymers of narrow molecular weight distributions at lower temperatures.

In order to find the characteristic nature of the present initiator systems, the effect of catalyst concentration of the polymerization was examined. When the 


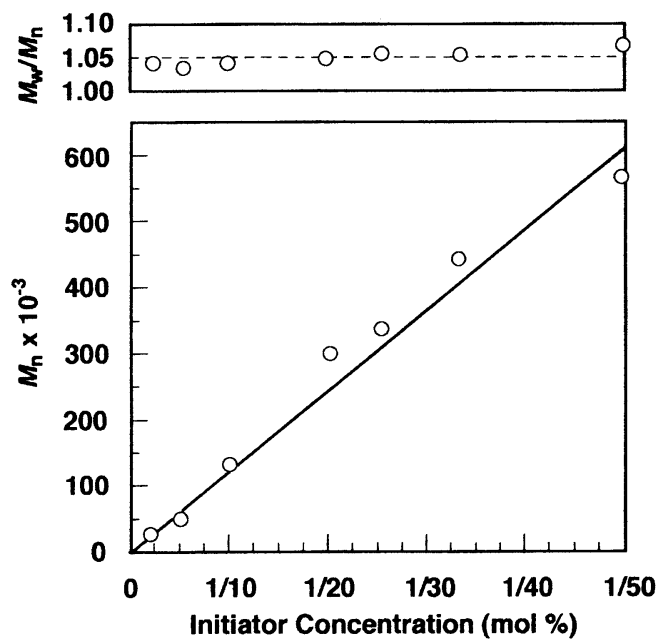

Fig. 2. The effect of the initiator concentration of the polymerization of ethyl acrylate.

initiator concentration was decreased from $0.1 \mathrm{~mol} \%$ to $0.02 \mathrm{~mol} \%$, we could obtain high molecular weight poly (EtA) of $M_{\mathrm{n}}=556,000$ with very narrow molecular weight distribution (Fig. 2). Thus, syntheses of high molecular weight poly (MeA), poly (EtA) and poly $(\mathrm{nBuA})$ with low polydispersity were for the first time achieved using organolanthanide (III) initiator (Table II).

The life time of the growing end was measured in toluene and in THF. The living polymerization of methyl acrylate $(200 \mathrm{mmol})$ proceeded in toluene with $\mathrm{SmMe}\left(\mathrm{C}_{5} \mathrm{Me}_{5}\right)_{2}$ (THF) (0.2 mol\% of monomer) and after completion of the polymerization (after $1 \mathrm{~min}$ ) the same volume of methyl acrylate $(200 \mathrm{mmol})$ was added to the resulting polymer to reinitiate the polymerization. However, in toluene no polymerization occurred. By contrast, the repolymerization occurred after holding the system for $1 \mathrm{~min}$ in THF solution. When the resulting polymerization system was held for $5 \mathrm{~min}$ in THF, ca. $70 \%$ of the growing and was survived. After $10 \mathrm{~min}$, all the growing end was destroyed at $0^{\circ} \mathrm{C}$. In cases of ethyl acrylate and butyl acrylate, repolymerization occurred in ca. 50\% conversion even after holding the polymerization system for 1-10 min in THF. The polymers thus formed by the second addition of monomers exhibit rather broad molecular weight distribution because of the initiator array should be destroyed already.

To penetrate into the initiation mechanism, the 1:1 or 1:2 reactions of $\mathrm{SmMe}\left(\mathrm{C}_{5} \mathrm{Me}_{5}\right)_{2}$ (THF) with methyl acrylate and t-butyl acrylate were examined. Quenching of the reaction mixture of methyl acrylate and $\mathrm{SmMe}\left(\mathrm{C}_{5} \mathrm{Me}_{5}\right)_{2}$ (THF) gave $\mathrm{CH}_{3} \mathrm{CH}_{2} \mathrm{CH}(\mathrm{COOMe})$ $\mathrm{CH}_{2} \mathrm{CH}(\mathrm{COOMe}) \mathrm{H}$ in $65-78 \%$ yield. More efficient initiating property was observed in the reaction of t-butyl acrylate with $\mathrm{SmMe}\left(\mathrm{C}_{5} \mathrm{Me}_{5}\right)_{2}$ (THF), which gave upon hydrolysis $\mathrm{CH}_{3} \mathrm{CH}_{2} \mathrm{CH}(\mathrm{COOtBu}) \mathrm{CH}_{2} \mathrm{CH}$ $(\mathrm{COOtBu}) \mathrm{H}$ in $96 \%$ yield at $0^{\circ} \mathrm{C}$. These results agree

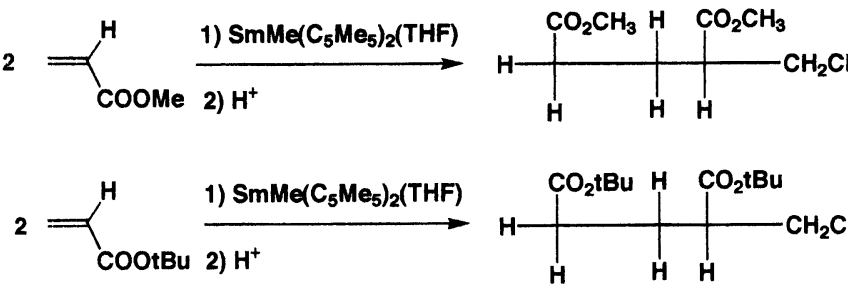

well with the hydrolysis result of the 2:1 molar reaction of MMA with $\left[\mathrm{Sm}\left(\mathrm{C}_{5} \mathrm{Me}_{5}\right)_{2} \mathrm{H}\right]_{2}$, which affords $\mathrm{Sm}\left(\mathrm{C}_{5} \mathrm{Me}_{5}\right)_{2}(\mathrm{MMA})_{2} \mathrm{H}$ as evidenced by X-ray analysis. ${ }^{8), 9)}$ Although the isolation of the 2:1 reaction product was unsuccessful in this case, we can readily estimate that the polymerization proceeds through the addition of acrylates to an enolate (Scheme 1). In fact, methyl acrylate can be polymerized by $\left[\mathrm{Y}_{(}\left(\mathrm{C}_{5} \mathrm{Me}_{5}\right)_{2} \mathrm{O}\right.$ $\left.\mathrm{CH}=\mathrm{CH}_{2}\right]_{2}$ initiator to give poly $(\mathrm{MeA})$ with $M_{\mathrm{n}}=$ 40,000 and $M_{\mathrm{w}} / M_{\mathrm{n}}=1.15$.

Temperature dependence of the tacticity was measured from $-78^{\circ} \mathrm{C}$ to $60^{\circ} \mathrm{C}$. However, little effect was observed in this temperature range. ${ }^{10)}$ Only a

Table II. Effect of initiator concentration ${ }^{\text {a) }}$

\begin{tabular}{lccccc}
\hline Monomers & $\begin{array}{c}\text { Initiator concentration } \\
\text { mol, \% }\end{array}$ & $10^{-3} M_{\mathrm{n}}$ & $M_{\mathrm{w}} / M_{\mathrm{n}}$ & $\begin{array}{c}\text { Conversion } \\
\%\end{array}$ & $\begin{array}{c}\text { Initiator efficiency } \\
\%\end{array}$ \\
\hline $\mathrm{MeA}$ & 0.05 & 148 & 1.05 & 84.5 & 86 \\
& 0.03 & 297 & 1.16 & 85.0 & 82 \\
$\mathrm{EtA}$ & 0.02 & 558 & 1.08 & 90.5 & 81 \\
& 0.014 & 775 & 1.15 & 75.0 & 69 \\
$\mathrm{nBuA}$ & 0.04 & 338 & 1.34 & 89.9 & 85 \\
\hline
\end{tabular}

a) Reaction conditions: initiator, $\operatorname{SmMe}\left(\mathrm{C}_{5} \mathrm{Me}_{5}\right)_{2}(\mathrm{THF})$; reaction temperature, $0^{\circ} \mathrm{C}$; solvent, toluene. 
Scheme 1
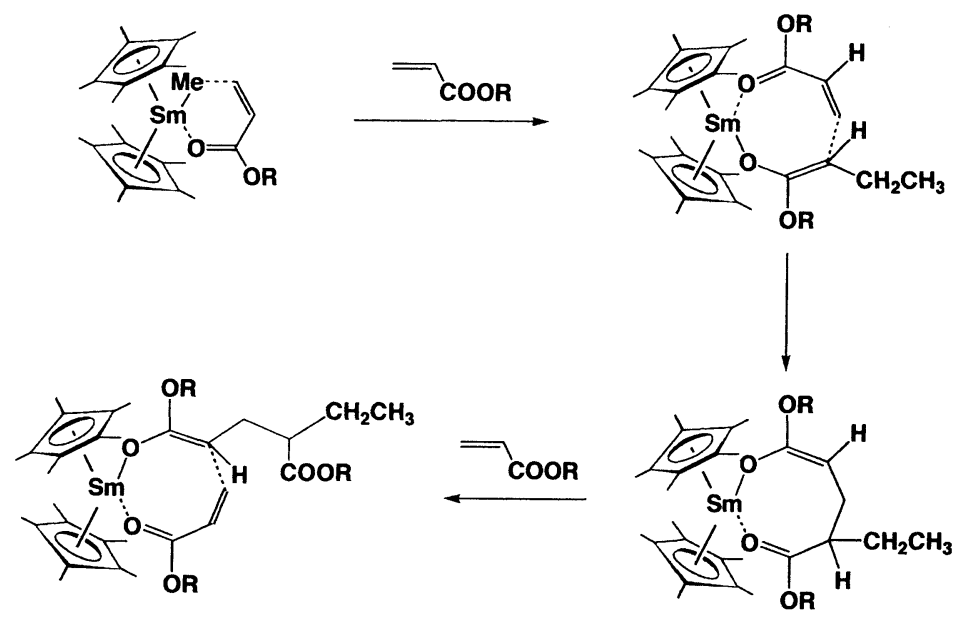

slight increase of syndiotacticity to $60 \%$ was observed in the polymerization of methyl acrylate using $\mathrm{SmMe}\left(\mathrm{C}_{5} \mathrm{Me}_{5}\right)_{2}(\mathrm{THF})$ as initiator.

Random copolymerizations of alkyl acrylates. The present system was found to conduct the living copolymerization of methyl acrylate with ethyl or butyl acrylate and also the copolymerization of ethyl acrylate with butyl acrylate. All systems gave high molecular weight polymers with extremely narrow molecular weight distribution by polymerization at $0^{\circ} \mathrm{C}$ for $10 \mathrm{~min}$. The resulting random copolymer composes of respective monomer component in a 1:1 ratio when conversion reaches $99 \%$.

To understand relative monomer reactivity, monomer reactivity ratio was determined using Fineman-Ross equation. The results are shown in Table III. The monomer reactivity ratio of methyl acrylate is higher than that of ethyl acrylate but is nearly the same as that of butyl acrylate. Monomer reactivity ratio of ethyl acrylate is smaller than that of buyl acrylate. By contrast to the acrylate systems, methyl methacrylate (MMA) exhibits much lower reactivity as shown in Table IV. Similarly, it has been reported that

Table III. Monomer reactivity ratio of alkyl acrylates monomers ${ }^{\text {a) }}$

\begin{tabular}{lccc}
\hline Monomers & $\mathrm{r}_{1}$ & $\mathrm{r}_{2}$ & $\mathrm{r}_{1} \cdot \mathrm{r}_{2}$ \\
\hline $\mathrm{MeA} / \mathrm{EtA}$ & 0.959 & 0.597 & 0.573 \\
$\mathrm{MeA} / \mathrm{nBuA}$ & 0.426 & 0.578 & 0.246 \\
$\mathrm{EtA} / \mathrm{nBuA}$ & 0.535 & 0.834 & 0.446 \\
\hline
\end{tabular}

a) Reaction conditions: initiator, $\mathrm{SmMe}$ $\left(\mathrm{C}_{5} \mathrm{Me}_{5}\right)_{2}(\mathrm{THF})$; initiator concentration, $0.2 \mathrm{~mol}$ $\%$; solvent, toluene.

methyl acrylate is much more reactive than MMA in anionic polymerization $\left[\mathrm{r}_{1}(\mathrm{MMA})=0.1, \mathrm{r}_{2}(\mathrm{MeA})=4.5\right.$, initiator $\left.=\mathrm{NaNH}_{2}\right],{ }^{11)}$ while their reactivities are comparable in radical initiating system using AIBN $\left[r_{1}(M M A)=1.0, r_{2}(M e A)=0.5\right] .{ }^{12)}$ Because of the different reactivities of MMA and alkyl acrylates in this initiating system, block copolymerization occurs preferentially even when a mixture of methyl methacrylate with methyl, ethyl or butyl acrylate was used. In fact, in the random copolymerization of MMA with nBuA (charged ratio 1:1), the content of MMA component in the resulting polymer is lower than $12 \%$ when conversion reaches $50 \%$.

Block copolymerization of alkyl acrylates with methyl methacrylate. ABA type triblock copolymerization of MMA/nBuA/MMA should provide rubber-like elastic polymer since MMA is hard segment while $\mathrm{nBuA}$ is soft segment, where hard segment will act as a nodule and soft segment as elastomer. To examine this possibility, we have demonstrated first $\mathrm{AB}$ type block copolymerizations. MMA (290 equivalents of initiator) was polymerized by $\left(\mathrm{C}_{5} \mathrm{Me}_{5}\right)_{2} \mathrm{SmMe}(\mathrm{THF})$ and $\mathrm{nBuA}$ (290 equivalents of initiator) was subse-

Table IV. Monomer reactivity ratio of MMA and alkyl acrylates monomers ${ }^{\text {a) }}$

\begin{tabular}{lccc}
\hline Monomers & $\mathrm{r}_{1}$ & $\mathrm{r}_{2}$ & $\mathrm{r}_{1} \cdot \mathrm{r}_{2}$ \\
\hline MMA/MeA & 0.015 & 19.9 & 0.299 \\
MMA/EtA & 0.008 & 15.9 & 0.127 \\
MMA/nBuA & 0.024 & 21.3 & 0.511 \\
\hline
\end{tabular}

a) Reaction conditions: initiator, $\mathrm{SmMe}$ $\left(\mathrm{C}_{5} \mathrm{Me}_{5}\right)_{2}(\mathrm{THF})$; initiator concentration, $0.2 \mathrm{~mol} \%$; solvent, toluene. 


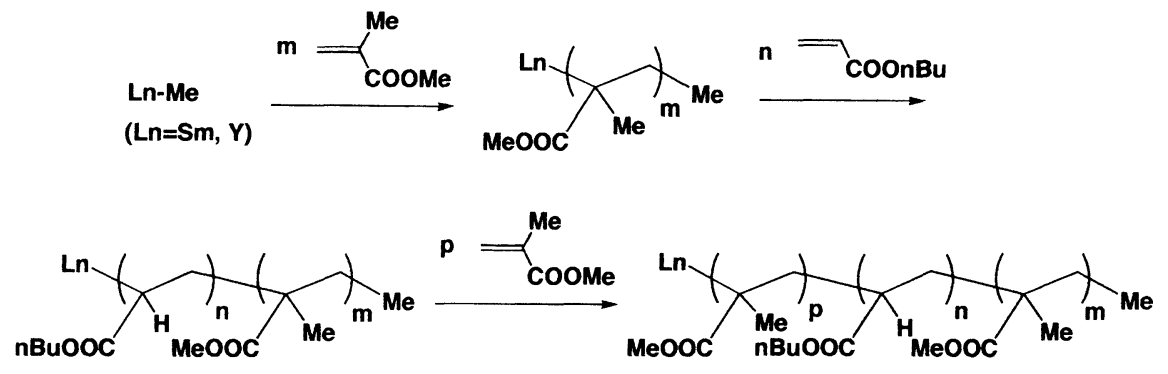

quently polymerized to give a $52: 48$ block copolymer of MMA with $\mathrm{nBuA}\left(M_{\mathrm{n}}=47,000, M_{\mathrm{w}} / M_{\mathrm{n}}=1.04\right)$. On the other hand, when $\mathrm{nBuA}$ was first polymerized and then MMA was next polymerized after holding $5 \mathrm{~min}$, the resulting polymer exhibits anomalously large molecular weight $\left(M_{\mathrm{n}}=217,000, M_{\mathrm{w}} / M_{\mathrm{n}}=1.19\right)$ because of the partial decomposition of the polymer growing end. Therefore, the addition of MMA should be completed in a short time after completion of the polymerization of $\mathrm{nBuA}$.

Thus, triblock copolymerization was conducted under the most suitable conditions, i.e. MMA was polymerized for $30 \mathrm{~min}$, then $\mathrm{nBuA}$ was added at once and after completion of polymerization of $\mathrm{nBuA}(2$ min), MMA was added (Scheme 2). In the first step, resulting poly (MMA) has $M_{\mathrm{n}} 15,000$ and $M_{\mathrm{w}} / M_{\mathrm{n}} 1.04$, and second step, poly (MMA-blo-nBuA) exhibits $M_{\mathrm{n}} 36,000$ and $M_{\mathrm{w}} / M_{\mathrm{n}} 1.05(\mathrm{MMA} / \mathrm{nBuA}=43: 57)$, and finally poly(MMA-blo-nBuA-blo-MMA) has $M_{\mathrm{n}}$ 144,000 and $M_{\mathrm{w}} / M_{\mathrm{n}} 1.09(\mathrm{MMA} / \mathrm{nBuA} / \mathrm{MMA}$ ratio= 13:72:15). Thus MMA block is connected to the growing end of poly (MMA-blo-nBuA). However, the growing end of poly (MMA-blo-nBuA) is partially died at that time and hence reproducibility of the present process is rather low. To improve this subject, a mixture of MMA and $\mathrm{nBuA}$ was added at once to the growing end of poly (MMA). In this case living triblock copolymerization proceeds ideally and we have obtained triblock copolymers composed of MMA/ $\mathrm{nBuA} / \mathrm{MMA}$ in a charged ratio. Mechanical properties of the resulting tri-block copolymers were evaluated by several methods (Table V). Homo poly (MMA) has large tensile modulus and large tensile strength but lacked the properties of elongation and izod impact strength. Furthermore, homo poly (MMA) does not show any decrease in compression set (typical rubber shows 10-20\%). By sharp contrast to the properties of poly (MMA), the triblock copolymer (8:72:20) shows $58 \%$ compression set. In this case Izod impact strength is not break $(>400 \mathrm{~J} / \mathrm{m})$, while hardness lowered to 20 JISA. Most interesting property lies in large elongation $(163 \%)$. by contrast to this, when the tri-block copolymers composed of MMA/nBuA/MMA in 6:91:3 or 25:51:24 ratio were used, the compression set increased to 97 or $101 \%$, respectively, to indicate that these polymers exhibit no elastic properties. Elongation of 25:51:24 triblock copolymer is $81 \%$ while that of $6: 91: 3$ copolymer is $246 \%$. Thus, suitable ratio is

Table V. Mechanical properties of triblock copolymers

\begin{tabular}{lccccc}
\hline Copolymer & $\begin{array}{c}\text { Tensile modulus } \\
\mathrm{MPa}\end{array}$ & $\begin{array}{c}\text { Tensile strength } \\
\mathrm{MPa}\end{array}$ & $\begin{array}{c}\text { Elongation } \\
\%\end{array}$ & $\begin{array}{c}\text { Izod impact strength } \\
\mathrm{J} / \mathrm{m}\end{array}$ & $\begin{array}{c}\text { Compression set } \\
\%, 70^{\circ} \mathrm{C}, 22 \mathrm{~h}\end{array}$ \\
\hline $\begin{array}{c}\text { Poly (MMA/nBuA/MMA) } \\
\text { (20: } 47: 33)\end{array}$ & 75 & 27 & 83 & 383 (N.B.) & 101 \\
$\begin{array}{c}\text { Poly (MMA/nBuA/MMA) } \\
\text { (25: } 51: 24)\end{array}$ & 46 & 22 & 81 & 390 (N.B.) & 103 \\
$\begin{array}{c}\text { Poly (MMA/nBuA/MMA) } \\
\text { (8: } 72: 20)\end{array}$ & 0.8 & 0.7 & 163 & 400 (N.B.) & 58 \\
$\begin{array}{c}\text { Poly (MMA/nBuA/MMA) } \\
\text { (6: } 91: 3)\end{array}$ & 0.2 & 0.1 & 246 & 410 (N.B.) & 97 \\
$\begin{array}{c}\text { Poly (MMA/EtA/MMA) } \\
\text { (26: } 48: 26)\end{array}$ & 119 & 22 & 276 & 34 & 62 \\
\hline
\end{tabular}


required to emerge elastic property for the triblock copolymers.

\section{References}

1) Kitano, T., Fujimoto, T., and Nagasawa, M. (1977) Polymer J. 9, 153.

2) a) Fayt, R., Forte, R., Jacobs, C., Jerome, R., Ouhadi, T., Teyssie, Ph., and Varshney, S. K. (1987) Macromolecules 20, 1442; b) Hautekeer, J. P., Varshney, S. K., Fayt, R., Jacobs, C., Jerome, R., and Teyssie, Ph. (1990) Macromolecules 23, 3893; c) Jacobs, C., Varshney, S. K., Hautekeer, R., Fayt, R., Jerome, R., and Teyssie, Ph. (1990) Macromolecules 23, 4024; d) Varshney, S. K., Jacobs, C., Hautekeer, J. P., Bayard, Ph., Jerome, R., Fayt, R., and Teyssie, Ph. (1991); Macromolecules 24, 4997.

3) a) Lochman, L., Janata, M., Machova, L., Vlcek, P., Mitera, J., and Muller, A. H. E. (1988) Polym. Prepr. Am. Chem. Soc. 29, 1; b) Janata, M., Muller, A. H. E., and Lochman L. (1990) Makromol. Chem. 191, 2253; c) Kunkel, D., Muller, A. H. E., Janata, M., and Lochman, L. (1991) Polym. Prepr. Am. Chem. Soc. 32, 301; d) Janata, M., Lochman, L., Vleck, P., Dybal, J., and Muller, A. H. E., (1992) Makromol. Chem. 193, 101.

4) a) Webster, O. W., Hertler, W. R., Sogah, D. Y., Farnham, W. B., and RajanBabu, T. V. (1983) J. Am. Chem. Soc. 105, 5706; b) Sogah, D. Y., Hertler, W. R.,
Webster, O. W., and Cohen, G. M. (1987) Macromolecules 20, 1473; c) Yu, H., Choi, W., Lim, K., and Choi, S. (1988) Macromolecules 21, 2893.

5) Hosokawa, Y., Kuroki, M., Aida, T., and Inoue, S. (1991) Macromolecules 24, 824.

6) Evans, W. J., Grate, J. W., Choi, W., Bloom, I., Hunter, W. E., and Atwood, J. L. (1985) J. Am. Chem. Soc. 107, 941.

7) Evans, W. J., Chamberlain, L. R., Ulibarri, T. A., and Ziller, J. W. (1988) J. Am. Chem. Soc. 110, 6423.

8) Yasuda, H., Yamamoto, H., Yokota, K., Miyake, S., and Nakamura, A. (1992). J. Am. Chem. Soc. 114, 4908.

9) a) Yasuda, H., Yamamoto, H., Yamashita, M., Yokota, K., Nakamura, A., Miyake, S., Kai, Y., and Kanehisa, N. (1993); Macromolecules 26, 7134; b) Yasuda, H., and Tamai H. (1993) Prog. Polym. Sci. 18, 1097.

10) Matsuzaki, K., Kanai, T., Kawamura, T., Matsumoto, S., and Uryu, T. (1973) J. Polym. Sci. Polym. Chem. Ed. 11, 861.

11) a) Bevington, J. C., and Harris, D. O. (1967) Polym. Lett. 5, 799; b) Shima, M., and Kotera, A. J. (1963) J. Polym. Sci. A1, 1115; c) Zubov, V. P., Valuev, L. I., Kavanov, V. A., and Kaegin, V. A. (1971) J. Polym. Sci. A9, 833; d) Madruga, E. L., Roman, J. S., and Rodriguez, M. J. (1983) J. Polym. Sci. Polym. Chem. Ed. 21, 2739.

12) Suchoparek, M., and Spvacek, J. (1993) Macromolecules 26, 102. 